\title{
The effects of Montessori training program for mothers on mathematics and daily living skills of 4-5 year-old Montessori children*
}

\section{Montessori anne destek eğitim programının Montessori eğitimi alan 4-5 yaş çocukların matematik ve günlük yaşam becerilerine etkilerinin incelenmesi}

\author{
Fatma Ülkü Yıldız ${ }^{1}$ Aysel Çağdaş²
}

\section{Article History}

Received : 04 April 2019

Revised : 08 May 2019

Accepted : 20 June 2019

Online : 02 July 2019

\section{Article Type}

Research Article

\begin{abstract}
This study investigated the effects of Montessori Training Program for Mothers (MTPM) on math and daily living skills of Montessori children ages 4 to 5 years old. Sample of the study included 19 Montessori pre-schoolers (8 and 11 children in experimental and control group respectively) who enrolled at an applied kindergarten affiliated to a university at Konya in 2016-2017 school year. Verified to be a reliable and valid measure for Turkish children, two subtests Mathematics (MATH) and Daily Living Skills (DLS) - of the Basic School Skills Inventory 3 (BSSI) were used to collect data. Tests were administered to the students as pre-test, post-test and follow-up test by their teachers. MTPM was administered to the mothers in the experimental group for 12 weeks-36 hours in total while control and experimental group children continued their Montessori education. Four weeks after the program was completed, BSSI-3-MATH and BSSI-3-DLS tests were re-administered as follow-up test. Mann Whitney U test and Wilcoxon Signed-Rank Test were used for the analysis of the study data. A comparison between the post-test mean scores of the experimental and control group showed a significant difference $(\mathrm{p}<.05)$ in math skills favoring the experimental group; no difference was found in pre and post-test scores in daily living skills $(\mathrm{p}>0.5)$. No significant difference was noted between the post-test and follow-up mean scores that experimental group children obtained on BSSI-3-MATH and BSSI-3-DLS, which showed that program gains were maintained.
\end{abstract}

Keywords: Montessori Method; Montessori Training Program for Mothers (MTPM); Mathematics; Daily Living Skills

Öz: Bu araştırma Montessori eğitim yöntemi ile eğitim alan 4-5 yaş çocuklarının annelerine verilen Montessori Anne Destek Eŭitiminin, çocukların matematik ve günlük yaşam becerilerine etkisini incelemeyi amaçlamıştır. Çalışma grubunda, 2016-2017 öğretim yılında Konya ilinde bulunan bir üniversiteye bağlı uygulama anaokuluna devam eden Montessori yöntemi ile okulöncesi eğitim alan, 8 deney, 11 kontrol olmak üzere toplam 19 çocuk yer almıştır. Araştırmada veri toplama aracı olarak geçerlilik ve güvenirlilik çalışması sonucunda Türk çocuklarına uygun olduğu tespit edilmiş olan "Temel Okul Becerileri Envanteri-3’ün Matematik ve Günlük Yaşam Becerileri” alt testleri uygulanmıstır. Testler deney ve kontrol grubu çocuklara öğretmenleri tarafından öntest ve sontest olarak uygulanmıştır. Kontrol grubu ve deney grubu Montessori yöntemi ile okulöncesi eğitimin almaya devam ederken, Montessori Anne Destek Ĕgitim Programı deney grubu annelerine 12 hafta ve toplamda 36 saat olarak uygulanmıştır. Eğitim programı bittikten 4 ve 12 hafta sonra kalıcılık testi için TOBE3- MAT ve TOBE-3- GYB tekrar uygulanmıştır. Araştırmadan elde edilen verilerin analizinde Mann Whitney U ve Wilcoxon İşaretli Sıralar Testi uygulanmıştır. İncelenen bulgular deney ve kontrol grubu arasında sontest puan ortalamaları, ( $\mathrm{p}<.05)$ Matematik de deney grubu lehine anlamlı bir farklılaşma görülmüştür. Deney grubu Günlük Yaşam Becerileri öntest-sontest değerlendirmelerinde ise $(\mathrm{p}>0.5)$ olduğu için bir farklılaşma bulunamamıştır. Deney grubu çocukların TOBE-3-MAT ve TOBE-3-GYB alt testi sontest-kalıcılık testi puan ortalamaları arasında $(\mathrm{p}>0.05)$ anlamlı bir farklılaşma olmaması çalışmanın kalıcılı̆̆ına vurgu yapmaktadır.

Anahtar Kelimeler: Montessori Yöntemi; Montessori Anne Destek Eğitim Programı; Matematik; Günlük Yaşam Becerileri

DOI: $\underline{10.24130 / \text { eccd-jecs.1967201932142 }}$

\section{Makale Geçmişi \\ Düzeltme : 08 Mayis 2019 \\ Kabul : 20 Haziran 2019}

Makale Türü

Araştırma Makalesi

\footnotetext{
* This article is produced by first author's doctoral thesis, under supervision of second author.

${ }^{1}$ Selcuk University, Faculty of Health Sciences, Department of Child Development, e-mail:fulkuyildiz@selcuk.edu.tr, ORCID: https://orcid.org/0000-0002-1164-515X

${ }^{2}$ Selcuk University, Faculty of Health Sciences, Department of Child Development, e-mail:aysel-cagdas@hotmail.com, ORCID: https://orcid.org/0000-0002-1082-3815
}

Atıf için/To cite this article:

Yıldız, F.Ü., \& Çağdaş, A. (2019). The effects of Montessori training program for mothers on mathematics and daily living skills of 45 year old Montessori children. Erken Cocukluk Çalssmalar Dergisi, 3(2), 278 299. doi:http://dx.doi.org/10.24130/eccd-jecs.1967201932142 


\section{INTRODUCTION}

Early childhood is a period in which children have a strong curiosity and a great desire to learn and they can very quickly adapt to the process of learning if they are still attending a preschool institution during this period, that means children have already left behind the critical periods of attachment; yet they are, at the same time, still experiencing a process of trust and reliance on parents, listening to their elders and generally complying with their directives. It is easier to work effectively with parents for their children in this period which includes increased sensitivity towards learning, teachers and family elders.

A child's first teacher is their parent(s) and a child's first school is the home. Parents need to be aware of the child's learning needs and acquire the ability to develop appropriate strategies. Montessori emphasizes that a child has a creative aptitude and a potential energy that help him build up a mental world from the real world around, and that the child will be in constant risk psychologically if there is no prepared environment to meet it (Montessori, 2016). A child is a baby until three years of age. Babies need their parents, especially their mothers. This environment should naturally be prepared by mothers. In the early years of life, the mother is as important to children as she is to babies and she has a great influence on the child. It is also known that maternal education in early childhood has a direct effect on parenting skills, and in turn, on the child (Erola, Jalonen and Lehti, 2016). Research has shown that parents who are involved in their child's education contribute not only to higher academic achievement but also to positive behaviours and emotional development (Epstein, 1986, Cai, 2003; Bower and Griffin, 2011; Alakoç Pirpir, 2011). It is significant that a mother receives essential education and puts it into practice in this period which is critical for the mother's education. But as of 2014 year, little to no research has been done specifically on the impact parent education programs have on boosting parents' knowledge of the Montessori Method or involvement (Meert, 2014).Since then, there has been research in the Montessori schools where the studies on parental education and participation are scientifically evaluated (Lau and Yau, 2015; Irving, 2017; Walls, 2018).Actually, these are rather reports than research studies.

The Montessori method is based on the theory that every child wants to learn. It allows the child to find the best and the easiest way of learning by trying out himself (Oğuz and Köksal Akyol, 2006). While setting its goals and expectations and providing an overview on the needs of school, the philosophy of Montessori program ensures that the child has the best possible Montessori experience. Montessori is an advanced model which is open to new developments. It considers the extreme sensitivity of the child towards the actions and expectations of adults. The basic principle 
is that the child wants to be partners with adults, copy their voice and actions, and become a part of that community (Kahn, 1990).

The distinctive characteristics of the Montessori method are that it is child-centred with a prearranged environment that allows self-learning and independence, focuses on the importance of education at an early age, offers individual education, and includes family involvement programs (Morrison, 2007).

Occurrence of the developmental stages in a certain order is not just the result of growth and maturation or of the influence of the environment. It actually occurs through the mutual interaction between them. According to Montessori, the interaction of the child with his environment reveals his mental and physical unity (Lillard, 2013; Toran and Temel, 2014). Children are undoubtedly affected considerably by their parents. The responsibility of the parents towards the child is not to be the ones who create him, but to help the child who needs to realize himself. According to Montessori, the role of the parents is to protect the child, not to create (Montessori, 2016). Nevertheless parents are generally guided by their previously acquired education habits. Havis (2009) argues that parents, due to their own unsolved childhood problems, could be involved in parenting practices that are likely to harm their children's Montessori education. This affects their expectations from school and teachers. Expectations, if they are positive and parallel to the education, increase the quality of education, whereas those rising from uncertainty may pose hindrances. Montessori underlines the fact that "adults will continue finding themselves in an unresolved problem until they deliberately face their mistakes and correct them. And children, when they become adults, in turn, will be victims of the same mistakes, which will be passed on from generation to generation" (Montessori, 2010). Parents and schools need to work together both for these kinds of problems and for their children.

Analysis of the research related to child development and education has returned the following results for stages; stage one - Institutional preschool education is important; stage two - schoolfamily collaboration is important for a qualified and effective education; final stage - children are more successful when supported by their parents besides school-family collaboration (Eastman, 1988; Satır, 1996 ; Çelenk, 2003; Kağıtçıbaşı, Bekman, Sunar and Cemaller, 2005). Accordingly, education of the child is a shared responsibility between the institution and parents. Research findings indicating the importance of family and maternal education emphasize that research studies are needed to examine the impact of such education programs on Montessori approach. 
Studies in the last decade in Turkey have shown that Montessori children have achieved more improvement than the traditional educational children (Öngören, 2008; Yiğit, 2008; Kaylli, 2010; Bayer, 2015; Kayll, 2015). These studies focus on the developmental characteristics of children, yet there is a need for further studies on Montessori method and family involvement. Such studies do not exist in Turkey. Also, it is noteworthy that parents of Montessori children (those with higher educational background) have lower expectations for the development of their children (Yildı, 2012). According to Dikkers, parental expectations that are incompatible with school may also damage communication (2013). Some researches demonstrated that of people who heard of Montessori, several had misconceptions about what this education method involves (Rambusch and Stoops, 1992; Lillard, 2005; Karna, 2013; Meert, 2014). This paradoxical situation also indicates that families have little knowledge about Montessori education. A longitudinal study conducted with parents of Montessori children and elementary school teachers found that their children demonstrated willingness to adapt to home and school and do the tasks that require certain skills (Yildız, 2010). Montessori schools ask parents to partner teachers to understand the Montessori philosophy, educate themselves, and practice the methods at home when possible (Haakmat, 2015). Considering the benefit when preschool education is supported at home by mothers, present study was needed to build life chains and strengthen the bond between home and school.

The interviews with the educators from Applied Kindergarten the sample group - emphasized the necessity of parental education program in the groups receiving Montessori education. In addition, the necessity for such an education program was also evident from the need analysis performed with the educators. In the need analysis obtained from parents, it was seen parents were willing to participate in training program and this training should primarily focus on daily living skills and mathematics (Yıldız, Çağdaş, 2017). This study was therefore built on the exploration of potential positive effects on children when daily living skills and math skills in Montessori education are supported by "a mother's training program".

This study therefore set out to investigate the effects of "Montessori Training Program for Mothers" (MTPM) provided to the mothers of 4-5 year-old Montessori children on their mathematics skills and daily living skills.

\section{METHOD}

\section{Design of The Study}


Prior to the study, parents of the children in the experimental and control groups were informed and their consent was obtained. The independent variable of the study is the "Montessori Training Program for Mothers". The dependent variables are "Mathematics" and "Daily Living Skills" of 48-60 month-old children receiving Montessori education. The study was designed in a way to demonstrate whether the independent variable would affect the dependent variables. True experimental (pre-test-post-test control group) design was employed. In pre-test-post-test control group designs, there are two groups formed by random assignment of subjects. In both groups, pre- and post-test measurements are performed. The presence of pre-tests in the design helps know the degree of similarity between the groups before the experiment and to correct the post-test results accordingly (Karasar, 2008).

\section{Sample of The Study}

Study population included Montessori classes from Applied Kindergarten which provides preschool education for 48-60 month-old children. Experimental and control groups were determined by random cluster sampling method. A total of 19 children were included in the study -8 in the experimental and 11 in the control group. Children's ages in the experimental and control groups averaged 52.6 months and 53.6 months respectively. Gender distribution of the experimental and control groups is shown in Table 1.

Table 1. Gender Distribution of Experimental and Control Groups

\begin{tabular}{lcccc}
\hline Gender & \multicolumn{2}{c}{ Experimental Group } & \multicolumn{2}{c}{ Control Group } \\
\hline & $\mathrm{n}$ & $\%$ & $\mathrm{n}$ & $\%$ \\
\hline Girl & 4 & 50.0 & 7 & 63.6 \\
\hline Boy & 4 & 50.0 & 4 & 36.4 \\
\hline Total & 8 & 100.0 & 11 & 100.0
\end{tabular}

As seen in Table 1, there were 8 children - 4 girls and 4 boys - in the experimental group, and 11 children -7 girls and 4 boys - in the control group. Study was conducted with 19 Montessori children from the ages of 48 and 60 months.

\section{Data Collection Instruments}

\section{Basic School Skills Inventory-3 (BSSI-3)}


Firstly, Basic School Skills Inventory-3 was purchased from the official web site with the purpose of research. BSSI-3 Mathematics and Daily Living Skills subtests were used in order to evaluate Math and Daily Living Skills of the children.

Internal consistency (Cronbach's Alpha), split half test and test-retest were performed for the reliability analysis of BSSI-3 Math and Daily Living Skills subtests.SSI-3 MATH and DLS validity was measured using construct, content, and concurrent validity. Yildız et al., reported that BSSI-3 Math and Daily Living Skills subtests were reliable and valid tools to use with Turkish children aged four to six years (2017).

\section{Basic School Skills Inventory 3 - Math:}

This 20-item subtest measures the knowledge of numerical concepts and arithmetic operations involved in beginning mathematics. Mathematical evaluation includes quantity, relation, equivalence, and simple arithmetic calculations, as well as recognizing, saying, selecting and writing numbers. Each item points to a skill. The full performance is successfully accomplished in the first grade at primary school.

\section{Basic School Skills Inventory 3 - Daily Living Skills:}

This 24-item subtest measures basic knowledge and skills typically required for participation in dayto-day activities in school. The areas to be evaluated primarily include self-care skills (hand-face washing, buttoning clothes, zippering, using a handkerchief or similar things). Motor skills are directly related to school activities (such as cutting with scissors and paperwork) and behaviours necessary for children to function independently (preparing the required materials for an activity). In addition, most items pertain to basic information that young children must acquire during the early years (reading the time from the analogue clock, telling the names of the days of the week). Items reflect a child's background of experience, including prior parental education and influence. Children doing well on these items are likely to be those who are considered independent and responsible in school (Hammill, Leigh, Pearson, Maddox, 1998).

\section{Montessori Training Program for Mothers}

Short and long-term needs analyses and systematic observations were performed to develop the training program. Answers to the open-ended questions directed to mothers, teachers and academics to determine the educational needs were evaluated with content and joint analyses. Whether mothers were willing to participate, how they wanted to participate, the topics they 
needed, participation times and the time of the follow-up were determined based on the results of the analyses. Data was collected on why teachers needed such a program, what topics mothers felt concerned about, how mothers as an obstacle affected the teachers and the quality of education, and what topics should be included. Regarding the needs analysis for academics, data was collected on what constitutes the social, scientific and supportive needs. A new needs analysis is recommended to carry out with participating mothers just before the training program is implemented. Based on the updated and obtained results, target group, needs of the mothers in the group, duration and period of the training and the goals to be achieved at the end of the program can be identified. Learning and communication methods and materials were developed on the basis of the goals identified. The target group was formed with the mothers willing to participate. Each week, two hours of pedagogical education and one hour of home-based practices were performed. A 36-hour training program - three hours over 12 weeks - was projected (Yıldız, Çağdaş, 2018)

\section{Data Analysis}

In the analysis of the data obtained from BSSI-3-MAT and BSSI-3-DLS, the study utilized Mann Whitney U test and Wilcoxon Signed Rank Test, a non-parametric test used to compare two related samples.

\section{RESULTS}

Conducted to explore the effects of "Montessori Training Program for Mothers" on 4-5 year-old Montessori children's math and daily living skills, the present study revealed the following results

In Table 2 was presented the comparison of the pre-test scores children earned on BSSI-3 Math and Daily Living Skills subtests before the MTPM was administered to the mothers of experimental group children.

Table 2. Results of the Mann Whitney-U Test for Pre-test Scores of Experimental and Control Groups

\begin{tabular}{|c|c|c|c|c|c|c|c|c|}
\hline \multirow[t]{2}{*}{ Pre-test } & \multirow[t]{2}{*}{ Group } & \multirow[t]{2}{*}{$\mathrm{n}$} & \multirow[t]{2}{*}{ Mean Rank } & Sum of & $\bar{x}$ & SD & $\mathrm{U}$ & $\mathrm{p}$ \\
\hline & & & & \multicolumn{5}{|l|}{ Ranks } \\
\hline \multirow[t]{2}{*}{ Mathematics } & Experimental & 8 & 9.69 & 77.50 & 19.25 & 6.84 & \multirow[t]{2}{*}{41.500} & \multirow[t]{2}{*}{.840} \\
\hline & Control & 11 & 10.23 & 112.50 & 14.81 & 2.95 & & \\
\hline Daily Living & Experimental & 8 & 10.12 & 81.00 & 36.75 & 7.37 & \multirow[t]{2}{*}{43.000} & \multirow[t]{2}{*}{.968} \\
\hline Skills & Control & 11 & 9.91 & 109.00 & 33.09 & 4.18 & & \\
\hline
\end{tabular}


In Table 2, it is seen that there is no significant difference $(p=.840)$ in "BSSI-3 MATH" pre-test scores between experimental and control group $(U=41.500, \mathrm{p}>0.05)$.

The average pre-test mean score on "BSSI-3 DLS" was found $\mathrm{p}=.968(\mathrm{U}=43.00, \mathrm{P}>0.05)$, which shows that there is no significant difference between the experimental and the control group in terms of daily living skills. The experimental and control groups were developmentally identical. The training program was started.

Table 3. Results of the Wilcoxon Signed-Rank Test for Post-test Scores of Experimental Group

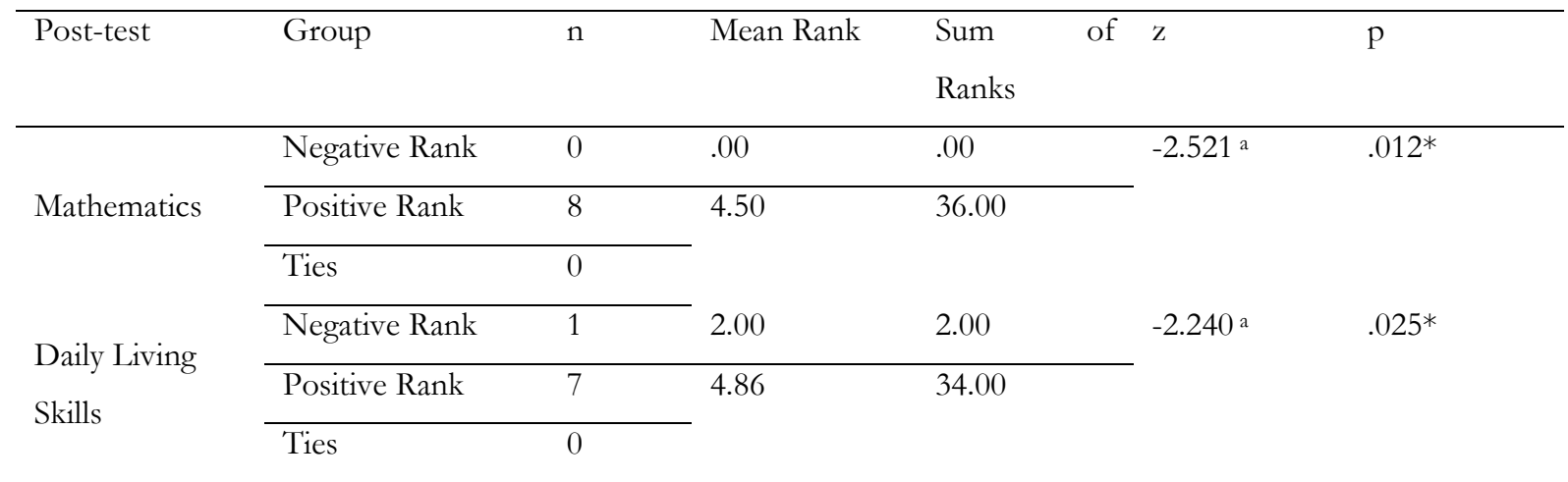

a Based on Negative Rank

In order to determine whether there was a significant difference between the BSSI-3-MATH and BSSI-3-DLS post-test mean scores of the experimental group, the Wilcoxon Signed-Rank test was performed and the results were shown in Table 3. The BSSI-3-MATH post-test mean scores ( $\mathrm{z}=$ $\left.-2.521^{\mathrm{a}}, \mathrm{p}<.05\right) \mathrm{p}=.012$ showed noticeable improvements in the experimental group. The scores from the BSSI-3 DLS pre-test and post-test were found to be $\left(\mathrm{z}=\mathrm{-}^{-} 2.240, \mathrm{p}<0.05\right) \mathrm{p}=.0 .25$.

Table 4. Descriptive Statistics for Pre-test-Post-test Scores of Experimental Group

\begin{tabular}{lllll}
\hline \multirow{2}{*}{ Test } & Experimental Group & $\mathrm{n}$ & $\overline{\mathbf{X}}$ & SD \\
\hline \multirow{2}{*}{ Mathematics } & Pre-test & 8 & 19.25 & 6.84 \\
\cline { 2 - 5 } & Post-test & 8 & 51.25 & 3.03 \\
\hline \multirow{2}{*}{ Daily Living Skills } & Pre-test & 8 & 36.75 & 7.37 \\
\cline { 2 - 5 } & Post-test & 8 & 60.00 & 3.41 \\
\hline
\end{tabular}

Descriptive statistics in Table 4 demonstrated that BSSI-3-MATH pre-test score was $\overline{\mathbf{x}}=19.25$ and increased to $\overline{\mathrm{X}}=51.25$ in the post-test. Similarly, an increase was also observed for BSSI-3-DLS; children in the experimental group scored $\bar{x}=36.75$ in the pre-test and their scores averaged $\overline{\mathrm{X}}=60.00$ in the post-test. These statistical analyses evidenced that experimental group children developed statistically in terms of BSSI-3-DLS. According to Table 4, the development of 
experimental group was statistically significant and MTPM made a positive contribution to the development of math and daily living skills of children.

Data in Table 5 and Table 6 shows whether developmental changes also occurred in the control group children who only received Montessori education, and whether they demonstrated a significant development like the experimental group involved in the MTPM.

Table 5. Results of Wilcoxon Signed-Rank Test for the Pre-test-Post-test Scores of Control Group

\begin{tabular}{|c|c|c|c|c|c|c|}
\hline $\begin{array}{l}\text { Pre-test Post- } \\
\text { test }\end{array}$ & Group & $\mathrm{n}$ & Mean Rank & Sum of Ranks & $z$ & $\mathrm{p}$ \\
\hline \multirow[t]{3}{*}{ Mathematics } & Negative Rank & 0 & .00 & .00 & \multirow[t]{3}{*}{$-2.952^{a}$} & \multirow[t]{3}{*}{$.003^{*}$} \\
\hline & Positive Rank & 11 & 6.00 & 66.00 & & \\
\hline & Ties & 0 & & & & \\
\hline \multirow[t]{3}{*}{ Living } & Negative Rank & 1 & 1.00 & 2.00 & \multirow{3}{*}{$-2.848^{a}$} & \multirow[t]{3}{*}{$.004^{*}$} \\
\hline & Positive Rank & 10 & 6.50 & 65.00 & & \\
\hline & Ties & 0 & & & & \\
\hline
\end{tabular}

aBased on Negative Rank

Table 6. Descriptive Statistics for the Pre-test - Post-test Scores of the Control Group

\begin{tabular}{lllll}
\hline Test & Control Group & $\mathrm{n}$ & $\overline{\mathrm{X}}$ & SD \\
\hline Mathematics & Pre-test & 11 & 14.81 & 2.95 \\
\cline { 2 - 5 } & Post-test & 11 & 30.09 & 4.10 \\
\hline Daily Living Skills & Pre-test & 11 & 33.09 & 4.18 \\
\cline { 2 - 5 } & Post-test & 11 & 46.90 & 4.55 \\
\hline
\end{tabular}

As seen in Table 5, the results of the Wilcoxon Signed Rank Test showed that BSSI-3-MATH pretest and post-test scores of the control group children were $(\mathrm{n}=11, \mathrm{z}=-2.952 \mathrm{a}, \mathrm{p}<.05) \mathrm{p}=.003^{*}$, which suggests a positive development in the math skills of these children. Their mean scores increased from $\bar{X}=14.81$ (pre-test) to $\bar{X}=30.09$ (post-test), as indicated by the statistical data in Table 6. These results showed that math scores of the control group increased significantly. Improvements in math and daily living skills were found in 4-5 year-old Montessori children in the control group.

When Table 5 is examined, the results of the Wilcoxon Signed Rank Test showed that BSSI-3-DLS pre-test and post-test scores of the control group children were $(\mathrm{n}=11, \mathrm{z}=-2.848 \mathrm{a}, \mathrm{p}<.05) \mathrm{p}=$ .004*, which suggests a positive development in the daily life skills of these children. Their mean scores increased from $\bar{x}=33.09$ (pre-test) to $\bar{x}=46.90$ (post-test), as indicated by the statistical data in Table 6. These results showed that daily life skill scores of the control group increased 
significantly. Improvements in math and daily living skills were found in 4-5 year-old Montessori children in the control group.

As in the control group children whose mothers were' not supported with MTPM, positive significant improvements were also observed in the control group who received Montessori education only.

Mann Whitney U and Wilcoxon Signed-Rank Test were performed to see if there was any difference between the BSSI-3-MATH and BSSI-3-DLSpost-test mean scores of the experimental and control groups (see Table 7 and Table 8).

Table 7. Results of Mann Whitney U Test for Post-test Scores of Experimental and Control Groups

\begin{tabular}{|c|c|c|c|c|c|c|c|c|}
\hline Post-tests & Group & $\mathrm{n}$ & Mean Rank & $\begin{array}{ll}\text { Sum of } \\
\text { Ranks }\end{array}$ & $\bar{x}$ & SD & $\mathrm{U}$ & $\mathrm{p}$ \\
\hline \multirow{2}{*}{ Mathematics } & Experimental & 8 & 14.38 & 115.00 & 51.25 & 3.03 & 9.000 & $.004^{*}$ \\
\hline & Control & 11 & 6.82 & 75.00 & 30.09 & 4.10 & & \\
\hline Daily Living & Experimental & 8 & 12.88 & 103.00 & 60.00 & 3.41 & 21.000 & .057 \\
\hline Skills & Control & 11 & 7.91 & 87.00 & 46.90 & 4.55 & & \\
\hline
\end{tabular}

Table 7 shows that the analysis of BSSI-3-MATH scores of the children in the experimental group and the control group resulted in $(U=9000, p<.05)$ p.004*, which was in line with the results of arithmetic mean. The experimental and control group scored $\bar{x}=51.25$ and $\bar{x}=30.09$ respectively. The arithmetic mean of the children in the experimental group was higher. These analyses indicate that MTPM made a greater contribution to the development of math skills in children aged 4-5 years.

The analysis of the data for the BSSI-3-DLS indicated that children in the experimental group had higher mean scores $(\overline{\mathrm{X}}=60.00)$ than those in the control group $(\overline{\mathrm{X}}=46.90)$, as shown in Table 7 . Results of the Mann Whitney $U$ test revealed a difference - but not a significant one - in favour of the experimental group. The difference in mean scores between two groups was found to be insignificant $(\mathrm{U}=21.000, \mathrm{p}=.057) \mathrm{p}>0.5$.

A follow-up test was carried out 4 and 12 weeks after the post-test to find out whether experimental group children maintained the acquired skills. Mann Witney U test and Wilcoxon Signed Ranks Test were applied in the analysis of the collected data. In order to determine whether there was a significant difference between the BSSI-3-MATH and BSSI-3-DLSpost-test and follow-up scores, the Wilcoxon Signed-Rank test was performed and the results were shown in Table 8. 
Table 8. Results of the Wilcoxon Signed-Rank Test for the Post-test - Follow-up Scores of the Experimental and Control Groups

\begin{tabular}{|c|c|c|c|c|c|c|}
\hline Post-test & Group & $\mathrm{n}$ & Mean Rank & Sum of ranks & $z$ & $\mathrm{p}$ \\
\hline \multicolumn{7}{|l|}{ Follow-up Test } \\
\hline \multirow[t]{3}{*}{ Mathematics } & Negative Rank & 5 & 4.30 & 21.50 & \multirow[t]{3}{*}{$-1.270^{a}$} & \multirow[t]{3}{*}{.204} \\
\hline & Positive Rank & 2 & 3.25 & 6.50 & & \\
\hline & Ties & 1 & & & & \\
\hline \multirow[t]{3}{*}{ Daily Living Skills } & Negative Rank & 5 & 5.50 & 27.50 & \multirow[t]{3}{*}{$-1.334^{a}$} & \multirow[t]{3}{*}{.182} \\
\hline & Positive Rank & 3 & 2.83 & 8.50 & & \\
\hline & Ties & 0 & & & & \\
\hline
\end{tabular}

a Based on Positive Rank

As summarized in Table 8, no significant difference is seen in "BSSI-3-MATH" Z score in the experimental group children $(\mathrm{z}=-1.270 \mathrm{a}, \mathrm{p}=.204) \mathrm{p}>0.05$. In addition, the descriptive statistics in Table 9 regarding the scores on Math post-test and follow-up test show a slight decrease from $\overline{\mathrm{X}}=51,25$ (post-test) to $\overline{\mathrm{X}}=46,75$. This score of the follow-up test $(\bar{X}=46,75)$ is higher than the score control group children achieved on posttest $(\overline{\mathbf{X}}=30,09)$, as seen in Table 7. In line with these findings, it seems that the MTPM provided a sustained effect on the mathematical skills of the experimental group children.

Table 9. Descriptive Statistics for the Post-test - Follow-up Scores of the Experimental Group

\begin{tabular}{lllll}
\hline Test & Experimental Group & $\mathrm{n}$ & $\overline{\mathrm{X}}$ & $\mathrm{SD}$ \\
\hline Mathematics & Post-test & 8 & 51.25 & 3.03 \\
\cline { 2 - 5 } & Follow-up Test & 8 & 46.75 & 3.41 \\
\hline Daily Living Skills & Post-test & 8 & 60.00 & 3.41 \\
\cline { 2 - 5 } & Follow-up Test & 8 & 54.87 & 3.34 \\
\hline
\end{tabular}

The data in Table 8 shows that there is no significant difference in Z score between DLS post-test - follow-up test in the experimental group children ( $\mathrm{z}=-1.334 \mathrm{a}, \mathrm{p}=.182) \mathrm{p}>0.05$. Also, the descriptive statistics in Table 9 related to the scores on DLS post-test and follow-up test demonstrate a slight decline from $\bar{x}=60,00$ (post-test) to $\bar{x}=54,87$. This score $(\bar{x}=54,87)$ is higher than the score control group children achieved on post-test $(\overline{\mathbf{x}}=46,90)$, as seen in Table 8 . As such, it could be concluded the MTPM made a sustained impact on the daily living skills of the children in the experimental group.

\section{DISCUSSION and INTERPRETATION}

In this chapter, findings from the present study were discussed and interpreted. Since the 1960s, various studies have been done on Montessori education method regarding parental education and 
involvement (Anonim, 2019; Kahn, 1990). However, no assessment study has been carried out to measure the effect on children of the parental education and involvement in Montessori method. As there is no research on the effects of Montessori education (e.g. mathematics and daily living skills) given to the family or one of the parents of Montessori children, it is not possible to discuss and interpret findings on the basis of one-to-one evaluation.

Accordingly, findings were discussed and interpreted under two main sections following the description of research process and main findings; the first section is focussing on the effectiveness of MTPM in "Math Skills" of pre-schoolers aged 4-5 years, and the second one is focusing on the impact of the training program on children's "Daily Living Skills".

This first section is presenting the results regarding the effectiveness of MTPM in the "Math Skills" of 4-5 year-old pre-schoolers; pre-tests were analysed at baseline and it was seen that control and experimental groups were equivalent (See Table 1). Control and experimental group children were receiving preschool Montessori education. Mothers of the children in the experimental group took part in MTPM. Pre-tests and Post-tests were evaluated after the intervention. Statistical analysis demonstrated that children in the experimental group made a significant progress in math and the difference observed was statistically significant (See Table 2 and 3). There occurred significant improvements in math skills in the control group children, as well (see Table 4 and 5). Post-tests were analysed afterwards for both groups, which revealed that experimental group achieved significant scores compared to the control group. On the other hand, it was seen that the statistical difference between the experimental and control group was not significant in daily living skills (See Table 6). The results of the follow-up test administered to experimental group were analysed statistically (See Table 7 and 8). It was observed that the effect of MTPM on children's math skills was still retained. The results were discussed and interpreted based on the findings of other studies examining the role Montessori plays in the development of mathematical skills.

The first section with a focus on the effectiveness of MTPM in the math skills of 4-5 year-old preschoolers revealed significant and positive developmental differences in mathematics in both experimental and control group. It is particularly noteworthy that the comparison of the post-test scores indicated this difference was significant favouring experimental group children. This result shows how effective maternal education and practices are for children to learn mathematics. It is known that parental-child interactions, especially encouraging and responsive parenting practices, have an important impact on children's academic development (Christian, Morrison and Bryant, 1998; Committee on Early Childhood Pedagogy, 2000). Cai (2003) examined American and 
Chinese families and concluded that parental participation is a statistically significant predictor of the mathematical success of their children. Mathematics is an important issue in education and is a critical part of academic preparation for children in the early stages of development (Uyanik, Kandır, 2010). It is important for the control group children to receive Montessori education as the absorption and internalization of the information is really fast during these ages - a period characterized by fast development process. These findings are in line with the results of the domestic research on mathematics and school readiness in Montessori preschool education. Using pre-test-post-test experimental research design, Yiğit (2008) investigated which method was more effective in 4-5-year-old children who received "number concept" education through Montessori method or traditional method. It was found that the number concept acquisition of the children receiving Montessori education was better than that of control group. Öngören, (2008) investigated the effectiveness of Montessori method in the acquisition of the concept of geometric shapes among preschoolers aged four to five years. Results of the research showed that the control group enrolled in the state preschool education program scored lower than Montessori children. Kayll (2010) examined the effect of Montessori method on preschool children's readiness for primary school and found that Montessori method positively contributes to the school readiness of primary school children and is more effective than the traditional preschool education program. Toran (2011) examined the effect of Montessori education method on concept acquisition, social adaptation and fine-muscle motor skills among children ages 4 to 6 years old. The findings revealed that Montessori sensorial education given to experimental group created a positive impact on concept acquisition of children, and practical life practices positively affected social adaptation and fine- muscle motor skills. Kayılı and Kuşçu (2012) compared social competence and school adjustment between two groups of primary school children and concluded that children with Montessori background had higher social competence and school adjustment scores compared to those from public preschools.

A literature searches in Turkish and English languages demonstrated that the studies abroad on Montessori mathematics education started after 1964. It is noteworthy that in the study conducted in 1969 with a pre-test-post-test design on Montessori education, the effects were found to be greatest or nearly greatest in all variables (Polk Lillard, 1972/2013). Longitudinal studies started in 1964 continued between 1965 and 1970. In the study carried out by Gross, Green, Clapp, (1970), samples were taken from four kinds of preschool institutions. Measures three years later revealed that the Montessori preschool classroom reached the optimal maturity for the first grade courses at primary school, followed by the school with traditional preschool education. Also Montessori preschoolers mostly responded "mathematics" when they were asked what they would you like to 
learn at school. Similarly, a body of research carried out between 1964-2017 investigated the developmental areas such as mathematics, school adjustment and academic achievement, and they found that Montessori approach produced better results among other education model. Regarding mathematics, Dohrmann (2003) compared two different groups of students with and without Montessori education and investigated the longitudinal effect of Montessori education on children's academic achievement. The average academic achievement of the students with Montessori education was found to be statistically significant compared to those without Montessori education; and the 7-year longitudinal research study showed that the students who received Montessori education were quite successful in mathematics and science. In their research project called Montessori Mathematics in Early Childhood Education, Chisnall and Maher (2007) investigated the mathematical concept development in children before they start school and indicated that Montessori could have a positive impact on children's numeracy knowledge. It was also reported that Montessori children demonstrated significantly higher achievement in relation to backward number word sequence (early addition and subtraction), and Montessori education offers more opportunities for children to develop higher order skills and concepts in early childhood. Another study was conducted to find out if Montessori method helps preschool students develop their mathematical competence, critical thinking and problem solving skills. The findings suggest that Montessori method helps students improve their math competence (Faryadi, 2017). In the study on minority Montessori students, positive differences were observed even after several years in the performance of students participating in the Montessori program (Dawson, 1987). To assess the social and academic impact of Montessori education, two studies were conducted in 1997 and 2003 (ages 3 to 6 and 6 to12 years). In five-year-olds, Montessori students were found to have higher levels of school readiness in reading and mathematical skills (Lillard, Else-Quest, 2006). Children attending public Montessori education between the ages of 3 and 11 were evaluated at primary school age, and it was seen children who had previously received Montessori education scored significantly higher in math and science (Dohrmann, Nishida, Gartner, Lipsky, Grimm, Kevin, 2007). In a study to determine to what extent Montessori curriculum supports the understanding of length measurement of primary school students, it was suggested that additional materials are needed for students to utilize in the classroom and that there are many opportunities available to measure with non-standard tools to fully understand the measurement and length (McIntosh, 2015). Reed (2016) investigated the understanding of place value concepts and abilities of Montessori students and found statistically significant differences favouring the Montessori students on conceptual tasks when grade 1 and all grades were compared. Chisnall and Maher (2007) reported that Montessori method is likely to offer more opportunities 
for children to develop higher order skills and concepts in early childhood. In line with these findings, it was concluded that MTPM was effective in the distinctive success of the experimental group children in mathematics, when compared to the experimental group.

This is the second section which summarizes the results regarding the effectiveness of MTPM in the "Daily Living Skills" of 4-5 year-old preschoolers; pre-tests were analysed at baseline and it was seen that control and experimental groups were equivalent (See Table 1). Control and experimental group children were receiving preschool Montessori education. Mothers of the children in the experimental group took part in MTPM. Pre-tests and Post-tests were evaluated after the intervention. Statistical analysis demonstrated that children in the experimental group made a significant progress in DLS and the difference between pre and post-test was found to be statistically significant (See Table 3). Statistical analysis of the pre-test and post-test in control group indicated significant improvements (see Table 4 and 5). Yet, post-tests showed no significant difference between experimental and control group regarding daily living skills (See Table 6). The results of the follow-up test administered to the experimental group were analysed statistically. It was observed that the effect of MTPM on children's daily living skills was still retained. The results of the BSSI-3 DLS indicated that there was no significant difference between DLS pre-test and post-test scores, neither in the experimental nor in the control group. However, arithmetic means pointed to a positive development in both groups. Practical life skills and sensory materials are important when preparing the child for scientific knowledge (Montessori, 2015.a., b.). Children in the experimental group could get an arithmetic mean of $\bar{x}=60$ on DLS test calculated from 23 items rated between 0 and 3 while those in the control group only achieved a mean score of $\overline{\mathrm{X}}=46.90$, which indicated a difference between the arithmetic means of both groups though it was not significant at .05 level of significance. It is thought that MTPM provided to the mothers of Montessori children contributes to the mathematics readiness in these children. Eccles (2005) argues that parents with higher education levels have stronger confidence in their child's academic abilities, and they also have higher expectations of their child. It is suggested in this study that when mothers are from university community and children are supported at home, this will make an impact on children's readiness for mathematics. It is easier to teach math to children who demonstrate adequate development and are ready to learn. Although practical life practices do not differ significantly according to the post-test scores of experimental and control group, they seem effective in helping children in the experimental group learn mathematical skills. This is because mothers in Montessori training program worked with their children by performing daily living practices after learning the philosophy and principles of Montessori method and then they started to practice mathematics. 
The mean scores for the experimental and control group revealed that the difference between the two groups was not significant. (See Table 7). Statistically significant improvements observed in the daily living skills of the control group children could be resulted from the fact that 48-60month-old children go through a natural and a rapid developmental process and this process for them is taking place as it should be. This result suggested the sensitive periods inherent in the Montessori philosophy. Montessori argues that in a certain sensitivity period, the child has an irresistible desire for certain knowledge or a skill (1961). The child's inner sensibilities help him choose from his complex environment what is suitable and necessary for his development. This is a temporary inclination. The interest or impulse directs the child to the surrounding special qualities and elements. It is limited to the acquisition of a particular quality (1909/1999). If a child has not been able to act according to the directives of his sensitive period, the opportunity of a natural conquest is gone, and once this opportunity is gone, it's gone forever (1936 / 2016.b.). This is supported by the findings revealed by Ohtoshi, Muraki and Takada (2008). They investigated the age and sex-related developmental differences of button ability, observing buttoning ability in children aged 36-83 months, focusing on age and sex differences. The study used a buttoning frame from Montessori materials. The frame was presented to the children exactly the same way as it is used in a Montessori classroom. No difference was observed between girls and boys, and unbuttoning and buttoning time decreased with age. The sensitive period for practical life skills is between the ages 2 and 4 years, and this sensitivity is lost after 4 years of age. Children mature to learn different types of skills at specific points in their development. (1936/1999).

Numerous studies have been conducted with the aim to investigate the contribution of practical life skills to children's development in critical periods. In a study with post-test control group design, Rule and Steward (2002) investigated the effect of Montessori practical life materials on the development of fine motor skills of preschool children, and found that the experimental group performed better. Bagby et al. (2015) carried out a quasi-experimental research to test the effect of Montessori practical life activities on the fine motor development and hand dominance of kindergarten children over a period of 8 months. The study revealed that the dominant hand showed significantly higher accuracy, speed and stability. Bayer (2015) carried out a study on the self-care skills which constitute one aspect of the practical life skills of pre-school children (3-5 years) in Montessori method. He concluded that Montessori method positively contributes to the self-care skills of preschool children.

Beside those on critical periods, some other studies have also been conducted to understand certain effects of Montessori practical life materials and activities. Stewart, Rule and Giordino (2007) 
examined the effect of 5-year-old children's motor skills on their attention and they found that Montessori children, as they possess improved motor skills, were successful in motor skills-based tasks that require extended attention. Shivji (2016) discovered that practical life activities have a consistent and positive impact on focussing and concentration. In his study on art and daily living activities, Ogabi (2016) observed that these two types of activities increased the concentration of children. Using a program built on Montessori practical life skills and activities such as peace table, food preparation and peace rose, Area (2016) found noticeable increases in children's social awareness and problem solving skills. Linebarger (2016) investigated the effects of involving children in the practical life curriculum on normalization in the Montessori toddler and primary classrooms. Findings verified that the process of normalization is facilitated in a beneficial way for the child when directed to a practical life activity. As suggested in these studies, practical life activities are important practices that contribute to children's development.

Based on the results of this study, it can be argued that the increase in mean scores from daily living skills in both control and experimental groups is due to Montessori preschool education program implemented in the classes. Activities related to Montessori "practical life skills" are often used during this period in the school. Though mothers of the experimental group children were supported by the MTPM, in neither group was there a statistically significant difference in the daily living skills. The reason could be that both experimental and control groups had the same school, classroom environment and teachers, and the parents might have influenced one another.

To conclude, the support given to mothers in mathematics education contributed more to the education received in school.

The lack of a significant difference between the experimental and control groups in practical life skills can arise from the following reasons;

1- Both experimental and control groups had the same school, classroom environment and teachers, and parents might have influenced each other,

2- It is a critical period for mathematics at around 4 years of age; whereas the sensitivity to practical life skills begins to disappear after 4 years of age,

\section{RECOMMENDATIONS}

Recommendations based on the study results: 
Parental education programs should be encouraged to support Montessori education and

education should be provided by paying attention to critical periods in enriched educational activities. (For example, research studies concerning mother education on practical life skills should be started at the ages of $1,5-2$ years.)

Longitudinal studies can be undertaken to explore the effects of the maternal education on Montessori children, and studies targeting parents or mothers should be expanded in a way to include subjects integrated in Montessori method such as reading, writing, speaking, biology, history and geography.

Montessori education is growing in popularity in our country, so the effects of "Montessori Training Program for Mothers" should be tested in other research studies by sampling experimental and control groups from different environments.

\section{REFERENCES}

Aarre, A. (2016). Effects of Peace Education and Grace and Courtesy Education on Social Problem-Solving Skills and Social Awareness.(Masters of Arts in Education Action Research Papers)188. Retrived from http://sophia.stkate.edu/maed/188(2019)

Alakoç Pirpir, D. (2011). Anne eğitim programmm 5-6 yaş çocuklarmm temel eğitime bą̧ı bulunuşluk düzeylerine etkisinin incelenmesi. (Yayımlanmamış Doktora Tezi) Selçuk Üniversitesi Sosyal Bilimler Enstitüsü, Konya.

Anonim. (2019). History of the American Montessori Society, 26 May1s 2019 tarihinde https://amshq.org/About-AMS/History-of-AMS adresinden erişildi.

Bagby, J; L.B.Barnard., T, Sulak., N,Jones., \& M.Walter. (2015). Educational gymnastics: The effectiveness of Montessori practical life activities in developing fine motor skills in kindergartners. Journal Early Education and Development. Volume 26(4), 594-607.

Bayer, A. (2015). Montessori Yönteminin Okul Öncesi (36-66 Ay) Çocuklarnnn Özbakım Becerilerine Etkisinin Incelenmesi. (Yayınlanmamış Yüksek Lisans Tezi) Selçuk Üniversitesi, Sosyal Bilimler Enstitüsü, Konya.

Bower, H. A., \& Griffin, D. (2011). Can the Epstein model of parental involvement work in a highminority, high-poverty elementary school ? A case study. Professional School Counseling, 15 (2), 77-87.

Cai, J. (2003) Investigating Parental Roles In Students' Learning Of Mathematics From A CrossNational Perspective .Mathematics Education Research Journal. 15(2), 87-106.

Çelenk, S. (2003). Okul Başarısının Ön Koşulu: Okul-Aile Dayanışması. İlköğretim Online, 2 (2), 2834. 
Chisnall, N., \& Maher, M. (2007). Montessori mathematics in early childhood education. Curriculum Matters, 3, 6-29

Christian, K., Morrison, F. J., \& Bryant, F. B. (1998). Predicting kindergarten academic skills: Interactions among child care, maternal education, and family literacy environments. Early Childhood Research Quarterly, 13(3), 501-521.

Committee on Early Childhood Pedagogy (2000). Eager to learn: Educating our preschoolers. The National Academies Press: Washington, DC

Dawson, M. (1987). Minority student performance: Is the Montessori Magnet School Effective? Retrived from (ERIC Document Reproduction Service, No. ED309881).

Dikkers, A. G. (2013) Family connections: Building Connections among home, school, and community, Childhood Education, 89(2), 115-116.

Dohrmann, K. R. (2003). Outcomes for students in a Montessori program: A Longitudinal study of the experience in the Milwaukee Public Schools. Association Montessori International of United States of America (AMI-USA). Report.

Retrived from http://d3n8a8pro7vhmx.cloudfront.net/umcs/pages/48/attachments/original/1375670 000/A3_Outcomes_for_Students_in_a_Montessori_Program.pdf?1375670000(2017)

Dohrmann, K. R., Nishida, T. K., Gartner, A., Lipsky, D. K., \& Grimm, K. J. (2007). High school outcomes for students in a public Montessori program. Journal of research in childhood education, 22(2), 205-217.

Eastman, B. (1988). Family involvement in education. (Bul.Kyn. Satır, 1996). Wisconsin State Department of Public instruction, Januvary.

Eccles, J. S. (2005). Influences of parents' education on their children's educational attainments: The role of parent and child perceptions. London review of education, 3(3), 191-204.

Epstein, J. L. (1986). Parents' reactions to teacher practices of parent involvement. The Elementary School Journal, 86(3), 277-294.

Erola, J., Jalonen, S., \& Lehti, H. (2016). Parental education, class and income over early life course and children's achievement. Research in Social Stratification and Mobility, 44, 33-43.

Faryadi, Q. (2017). The Application of Montessori Method in Learning Mathematics: An Experimental Research. Online Submission, 4, 1-14.

Gross., R., B. Green., Clapp, D. (1970) The Sands School Project: Thirtby Year Results. Cincinnati Univ., Ohio. Dept. of Psychology.

Haakmat, M. (2015). Reaping the benefits of parent education. Montessori Life, 27(1), 30-33.

Hammill, D. D., Leigh, J. E., Pearson, N. A. \& Maddox, T. (1998). Basic School Skills Inventory A Readiness Measure for Teacher. (3rd edition) Austin-Texsas: Pro-ed an International Publisher. URL:Texsas.http://www.proedinc.com/customer/productView.aspx?ID=139(2016).

Havis, L. (2009). Home-school relations. The Montessori Observer, 30(1), 2-4. 
Irving, Sarah C.,(2017) "Montessori Parent Education: An Action Research Report".Masters of Arts in Education Action Research Papers. 208. http://sophia.stkate.edu/maed/208(2019).

Kağıtçıbaşı, Ç., Sunar, D., Bekman, S., Cemaller, Z. (2005). Erkeen Müdahalenin Erişskinlikte Süren Etkileri. Erken Destek Projesinin İkinci Takip Çalsmasmmn Ön Bulgular. İstanbul: Anne-Çocuk Eğitim Vakf1 Yayınları.

Kahn, D. (1990). Implementing Montessori Education in the Public Sector. Instituon: North American Montessori Teachers Association, Cleveland Heights. Implementation.(Ed. Kahn, D.)., OH.NAMTA Sayfa:474. Retrieded from, https://archive.org/details/ERIC_ED327286.(2017)

Karasar, N. (2008). Bilimsel Araștırma Teknikleri. (18. Bask1). Ankara: Nobel Yayın.

Karna, A. (2013). Why Montessori? from a parent's perspective. Montessori Life ,25(1), 24-29.

Kayılı, G. (2010). Montessori Yönteminin Anaokulu Cocuklarmm İlkögretime Hąır Bulunuşluklarna Etkisinin Incelenmesi. (Yayınlanmamış yüksek lisans tezi) Selçuk Üniversitesi, Sosyal Bilimler Enstitüsü, Konya.

Kayıl1, G. (2015). Sosyal beceri eğitimi program ile desteklenen montessori yönteminin anaokulu çocuklarmmn duygular anlama ve sosyal problem çözme becerilerine etkisi. (Yayınlanmamış Doktora Tezi.) Selçuk Üniversitesi, Sosyal Bilimler Enstitüsü, Konya.

Kayıl1, G., \& Kuşcu, Ö. (2012). Examination of social competence and school adjustment of primary school children who had pre-school education with the Montessori method. Journal of Teaching and Education, 1(2), 399-405.

Lau, D., Yau, R(2015) From Zero China Montessori Parent Education in Hong Kong and Greater China. Montessori Life. Retrieved from https://www.hkmrda.org/site/assets/files/1217/from zero to infinitymontessori parent education in hong kong and greater china.pdf (2019).

Lillard, A., \& Else-Quest, N. (2006). Evaluating montessori education. Science, 313(5795), 18931894.

Lillard, A.S. (2005). Montessori: The Science Behind The Genius. New York: Oxford University Press.

Lillard, P. P.(2013). Montessori Modern Bir Yaklaşım. (Çev: O. Gündüz). İstanbul: Kaknüs Eğitim Yayınlar1

Linebarger, L. (2016). Beneficial Effects of Practical Life Activities and Normalization.(Masters of Arts in Education Action Research Papers.) $183 . \quad$ Retrived from http://sophia.stkate.edu/maed/183

McIntosh, K.L.,(2015). Montessori Mathematics Curriculum And Lower Elementary Students Understanding Of Length Measurement (Masters of Arts in Education Action Research Papers)148. Retrieved from http:/ / sophia.stkate.edu/cgi/viewcontent.cgi?article=1149\&context=maed (2019). 
Meert, Pauline. (2014). Montessori- What Is It All About?. Retrieved from Sophia, the St. Catherine University repository website: https://sophia.stkate.edu/maed/52

Montessori, M. (1997). Çocuk Ĕğtimi, Montessori Metodu, (Çev: Güler Yücel), (5. Baskı), İstanbul: Özgür Yayınları.

Montessori, M. (1999). Annelik sanatı. (Çev. Cemal Külhanbeyi). Bahar Yayınevi, İstanbul.

Montessori, M. (2010). The child in the family. Amsterdam: Pierson Publishing Company.

Montessori, M. (2015). Emici Zibin.(Çeviren: Okhan Gündüz) İstanbul: Kaknüs Yayınlar1.:665.

Montessori, M. (2016). Çocukluğun Sırr.(Çev. S. Bilgin) İstanbul: Kaknüs Yayınları:673.

Montessori, M. (2016.b.). Çocuğun Keșfi (Çeviren: Okhan Gündüz) İstanbul: Kaknüs Yayınlar1.

Montessori, M. M. (1961). Maria Montessori's contribution to the cultivation of the mathematical mind. International Review of Education, 7(2), 134-141.

Montessori, M.(1912)The Montessori Method Scientific Pedagogy As Applied To Child Education In "The Children's Houses" With Additions And Revisions By The Author (Translated From The Italian By Anne E. George) from http://yuoiea.com/uoiea/assets/files/The\%20Montessori\%20Method.pdf(2019)

Morrison, G. S. (2007 ). Early Childhood Education Today (10th Edition). New Jersey: Pearson Education.

Oghabi, M. (2016). "The effects of daily art activities on attention in elementary students an action research report by marjan". (Masters of Arts in Education Action Research Papers) 182. Retrieved from http://sophia.stkate.edu/maed/182(2019)

Oğuz, V. ve Köksal Akyol, A. (2006). Çocuk Eğitiminde Montessori Yaklaşımı. Cukurova Üniversitesi Sosyal Bilimler Enstitïsü Dergisi, 15 (1), 243-256.

Ohtoshi, T., Muraki, T., \& Takada, S. (2008). Investigation of age-related developmental differences of button ability. Pediatrics International, 50(5), 687-689.

Öngören, S. (2008). Okul öncesi eğitim kurumlarna devam eden dört - beş yas grubu çocuklarna geometrik şekil kavramı kazandırmada montessori eğitim yönteminin etkililiği. (Yayınlanmamış Yüksek Lisans Tezi) Selçuk Üniversitesi, Sosyal Bilimler Enstitüsü, Konya.

Rambusch, N. M. \& Stoops, J. A. (1992). The Authentic American Montessori School: A Guide To The Self-Study, Evaluation, And Accreditation Of American Schools Committed To Montessori Education. New York: AMS and the Commission on Elementary Schools of the Middle States Association.

Reed, M. K. (2008). Comparison of the place value understanding of Montessori elementary students. Investigations in Mathematics Learning, 1(1), 1-26.

Rule, A. C., \& Stewart, R. A. (2002). Effects of practical life materials on kindergartners' fine motor skills. Early Childhood Education Journal, 30(1), 9-13. 
Satır, S. (1996). Öz̧el tevfik fikeret lisesi ögrrencilerinin akademik başarnlarylla ilgili annebaba davranıslarn ve akademike başaryy arturmaya yönelik anne-baba eğitim gereksinmelerinin belirlenmesi. (Yayınlanmamış. Yüksek Lisans Tezi)Ankara Üniversitesi Sosyal Bilimler Enstitüsü. Ankara

Shivji, Munir. (2016). The Effects of movement interventions on focus and concentration in toddler montessori classrooms. Retrieved from Sophia, the St. Catherine University repository website: https://sophia.stkate.edu/maed/180(2019)

Stewart, R. A., Rule, A. C., \& Giordano, D. A. (2007). The effect of fine motor skill activities on kindergarten student attention. Early Childhood Education Journal, 35(2), 103-109.

Toran, M. (2011). Montessori Yönteminin Cocuklarn Kavram Edinimi, Sosyal Uyumlar Ve Küçïk Kas Motor Becerileri Üzerindeki Etkisinin Incelenmesi. (Yayınlanmamış Doktora Tezi) Gazi Üniversitesi Eğitim Bilimleri Enstitüsü. Ankara.

Toran, M., \& Temel, F.Z. (2014). Montessori yaklaşımın çocukların kavram edinimi üzerindeki etkisinin incelenmesi, İlkögretim Online, 13(1),223-234.

Uyanık, Ö., \& Kandır, A. (2010). Okul öncesi dönemde erken akademik beceriler. Kuramsal Eğitimbilim Dergisi, 3(2), 118-134.

Walls, J. K. (2018). To What Extent Do Parents of Montessori-Educated Children" Do Montessori" at Home? Preliminary Findings and Future Directions. Journal of Montessori Research, 4(1), 14-24.

Yiğit, T. (2008). Okulöncesi Eğitim Kurumlarnnda Montessori Ve Geleneksel Ögrretim Yöntemleri Alan Cocukların Sayı Kavramım Kaz̧anma Davranışlarnm Karşılaştırlması. (Yayınlanmamış Yüksek Lisans Tezi) Selçuk Üniversitesi, Sosyal Bilimler Enstitüsü, Konya.

Yıldız, F. Ü ve Çağdaş A. (2017). Montessori Anne Destek Eğitim Programı(MADEP). 26. International Conference on Edicational (ICES/UEBK-2017) Bildiri Özetleri sayfa:2507-2508

Yıldız, F. Ü ve Çağdaş, A. (2018). Montesson Anne Destek Eğitim Programi'nn Haz̧rlanması, Uygulanması Ve Değerlendirilmesi. IV. International Academic Research Congress. Ankara: Çizgi yayınevi.

Yildız, F. Ü. (2011). Adaptation of the children to primary schools educated by Montessori method. International Journal of Multidisciplinary Thought, 1(4), 349-354.

Yildız, F. Ü. (2012). The expectations of parents from Montessori preschool education. Journal of Teaching and Education, 1(6), 283-294.

Yıldız, F. Ü., Çağdaş, A., \& Kayılı, G. (2017). Basic school skills inventory-3: Validity and reliability study. Journal of Education and Training Studies, 5(7), 28-36. 